resembled those seen in skin biopsy specimens and oral mucous membrane lesions (Koplick spots) from children with measles. ${ }^{3}$

An alternative explanation of the skin lesions would be erythema multiforme or a fixed drug eruption. Although some of the histopathological results might be compatible with these diagnoses, ${ }^{45}$ the presence of multinucleate keratinocytes and inclusion bodies would be unusual. No history was obtained, on close questioning, of taking any drug, including proprietary and traditional remedies.

Although the cause of the signs and symptoms seen in these children is unknown there were various clinical aspects that suggest a viral aetiology and, by extrapolation, a viral association with epithelial cell antibody. All our patients had symptoms suggestive of a preceding viral illness; evidence of streptococcal infection was found in only one. None of the children had parvovirus antibodies. Two of the patients lived together, and their mother and the parents and siblings of the boy in case 6 all tested positive for the antibody, which is compatible with an infectious aetiology. The patients all came from south east London but apart from the two sisters had not been in contact with each other.

Systemic and renal disease associated with circulating antibodies and immune complexes is well recognised in systemic lupus erythematosus, Goodpasture's syndrome, Wegener's granulomatosis, and small vessel polyarteritis. ${ }^{6}$ The presence of antibodies in these disorders does not necessarily, however, correlate with the severity and spectrum of disease. In Goodpasture's syndrome the antibody is known to be pathogenic but in other disorders the role of circulating antibodies and immune complexes is less clear. Antibodies have also been implicated in certain skin disorders. Antibodies to intercellular components of the stratum spinosum have been found in $90 \%$ of cases of pemphigus vulgaris, and in $70 \%$ of cases of bullous pemphigoid antibodies to basement membrane zone antigens of the stratified epithelium have been found.?

JD was supported by Action Research for the Crippled Child.

1 Harmer AW, Haskard D, Koffman CG, Welsh KI. Novel antibodies associated with unexplained loss of renal allografts. Transpl Int 1990;3:66-9.

2 Harmer AW, Rigsden SPA, Koffman CG, Welsh KI. Preliminary report: dramatic rise in renal allograft failure rate. Lancet 1990;335:1184-5.

Ackerman AB, Suringa DWR. Multinucleate epidermal cells in measles. Arch Dermatol 1971;103:180-4.

4 Bedi TR, Pinkus H. Histopathological spectrum of erythema multiforme.

Brf Dermatol 1976;95:243-50.
5 Lever WF, Schaumberg-Lever G, eds. Histopathology of the skin. Philadelphia: J B Lippincott, 1983:259-70.

6 Pusey CD, Venning MC, Peters DK. Immunopathology of glomerular and interstitial disease. In: Schrier RW, Gottschalk CW, eds. Diseases of the kidney. 4th ed. Boston: Little Brown, 1988:1827-83.

7 Beutner EH, Chorzelski TP, Jablonska S. Clinical significance of immunofuorescence tests of sera and skin in bullous diseases. In: Beutner EH, Chorzelski TP, Kumar V, eds. Immunopathology of the skin. 3rd ed. New York: John Wiley, 1987:177-205.

(Accepted 14 May 1991)
Department of Paediatrics, Kolding Hospital, Denmark

Ole D Wolthers, MD, research fellow

Søren Pedersen, MD, consultant paediatrician

Correspondence to: Dr O D Wolthers, Siriusvej 9, DK-8270 Højbjerg,

Denmark.

BMf 1991;303:163-5

\title{
Growth of asthmatic children during treatment with budesonide: a double blind trial
}

\author{
Ole D Wolthers, Søren Pedersen
}

\begin{abstract}
Objective-To determine whether the inhaled glucocorticosteroid budesonide has any adverse effect on short term linear growth in children with mild asthma.

Setting-Outpatient clinic in secondary referral centre.

Patients -15 children aged 6-13 years with normal statural growth velocity during the previous year, no signs of puberty, and no use of systemic or topical steroids in the two months before the study.

Design of interventions-Double blind, randomised crossover trial with two active periods in which budesonide was given in divided daily doses of $\mathbf{2 0 0}$ $\mu \mathrm{g}$ and $800 \mu \mathrm{g}$. During run in and two washout periods placebo was given. After the second washout period the children received open treatment with 400 $\mu \mathrm{g}$ budesonide daily. All periods were of 18 days' duration.

Main outcome measure-Growth of the lower leg as measured twice a week by knemometry.

Results-Mean growth velocity of the lower leg was $0.63 \mathrm{~mm} /$ week during run in and during washout $0.64 \mathrm{~mm} /$ week. Budesonide treatment was associated with a significant dose related reduction of growth velocity: the mean reduction in growth velocity during treatment was $0 \cdot 11$ ( $95 \%$ confidence interval -0.15 to 0.37$) \mathrm{mm} /$ week with $200 \mu \mathrm{g}$ budesonide and $0.36(0.13$ to 0.59$) \mathrm{mm} /$ week with $800 \mu \mathrm{g}$ budesonide ( $<<0.05 ;$ Page's test). During treatment with $400 \mu \mathrm{g}$ budesonide a reduction of $0.17(-0.10$ to 0.45 ) $\mathrm{mm} /$ week was found.
\end{abstract}

Conclusions - Treatment with inhaled budesonide is associated with a dose related suppression of short term linear growth in children with mild asthma.

\section{Introduction}

The risk of systemic side effects of inhaled glucocorticosteroids in children with asthma has been much debated ${ }^{1-7}$ Special attention has been paid to the risk of growth suppression, ${ }^{8-18}$ but studies on this issue have been associated with methodological problems and conflicting results have been reported. ${ }^{719}$ Recently, however, knemometry has been established as a powerful tool for monitoring short term linear growth in children, measuring changes in lower leg length with an accuracy of $0 \cdot 09-0 \cdot 16 \mathrm{~mm} .{ }^{20-22} \mathrm{It}$ has been suggested that this method may be a useful physiological alternative or adjunct to the biochemical measures of systemic effects of topical steroids in children. ${ }^{23}{ }^{24}$ The aim of the present study was to investigate by means of knemometry whether the inhaled glucocorticosteroid budesonide has any adverse effect on short term linear growth in children with mild asthma.

\section{Patients and methods}

When planning the study we estimated the standard deviation of the mean growth rate of the lower leg to be $0.20 \mathrm{~mm} /$ week. $^{25}{ }^{26}$ On this assumption we calculated that 12 patients would be sufficient for a power of 0.90 to detect a $50 \%$ reduction in growth rate, which was considered a clinically relevant difference. ${ }^{27}$ A $20 \%$ rate of withdrawals was estimated, thus increasing the study population by three patients. 
Nine boys and six girls aged 6 to 13 (mean 9.5) years entered the study. All suffered from mild asthma treated with inhaled $\beta_{2}$ stimulants as needed. None had received treatment with inhaled or oral glucocorticosteroids in the two months before the study, and no other drugs were taken during the study period. All children were preadolescents without any signs of puberty. Their growth velocities during the previous year ranged from 4.0 to $9 \cdot 0$ (mean $5 \cdot 6$ ) $\mathrm{cm} /$ year. Height at the beginning of the trial varied from -1.75 to +2.18 (mean 0.03 ) standard deviation scores and weight from 22.0 to 48.5 (mean 31.4 ) $\mathrm{kg}$. The study was approved by the local ethical committee and informed consent was obtained from all children and their parents.

The study design was a randomised, double blind, crossover trial with four periods of 18 days. In periods 1 (run in) and 3 (washout) placebo was given, and in periods 2 and 4 the children took $200 \mu \mathrm{g}$ and $800 \mu \mathrm{g}$ budesonide a day. Treatment order was allocated by a computerised randomisation scheme prepared in balanced blocks. Budesonide was taken in the morning and in the evening as two puffs from a conventional pressurised metered dose inhaler with a Nebuhaler. Before the study all children had shown optimal use of the inhaler, and inhalation technique was monitored at every visit. As a measure of compliance the aerosols were weighed before and after each period and the number of puffs used by each patient was calculated.

Knemometry measurements and monitoring of the asthmatic condition of the children were performed as described in an earlier study. ${ }^{24}$ To minimise the risk of a possible suppressive effect of a reduced pulmonary function on growth, only data from children showing a variation of less than $15 \%$ in pulmonary function between the various periods were used for analysis.

At the end of the scheduled study we decided to investigate also the dose of $400 \mu \mathrm{g}$ budesonide per day. Therefore the study was prolonged with a placebo period (period 5) and a period of giving $400 \mu \mathrm{g}$ budesonide (period 6). To reduce the number of visits knemometry was performed only once a week during period 5.

On the basis of all measurements in periods $1-4$ and 6 the growth velocities of the lower leg were calculated for each period by linear regression analysis and expressed as $\mathrm{mm} /$ week. Data from period 5 were excluded from analysis because few measurements had been made in this period. ${ }^{2021}$ Growth velocities were compared by the method described for crossover trial designs. ${ }^{28}$ Neither period nor carryover effects were found. Page's test was used to evaluate the dose related influence of budesonide on growth velocities in the lower leg. ${ }^{29}$

\section{Results}

One girl was withdrawn because she presented with a febrile respiratory disease and a $20 \%$ reduction of pulmonary function during run in. Of the fourteen children who completed the study according to the protocol there were seven in each blinded dose sequence group. Compliance with dosage regimen varied from $88 \%$ to $105 \%$ (mean $96 \%$ ) during treatment with $200 \mu \mathrm{g}$ budesonide and from $86 \%$ to $102 \%$ (mean $94 \%$ ) during the $800 \mu \mathrm{g}$ period. During treatment with 400 $\mu \mathrm{g}$ budesonide compliance varied from $81 \%$ to $112 \%$ (mean 91\%).

Because of school holidays the run in period was extended in six children and the first treatment period in eight children was extended to a total duration of 20 23 days. The technical error of the knemometer (that is, the mean standard deviation of three successive estimations of lower leg length) was $0.09 \mathrm{~mm}$.

No significant variation was seen in pulmonary function or in consumption of $\beta_{2}$ stimulants between the various periods (table). The figure shows mean and individual lower leg growth velocities. The mean growth velocities during run in and the first washout period were almost identical. Budesonide treatment resulted in a significant dose related reduction in mean lower leg growth velocity both when the $400 \mu \mathrm{g}$ period was excluded from the calculations $(p=0 \cdot 04, z=-2 \cdot 1)$ and when this period was included $(p=0 \cdot 03, z=-2 \cdot 2)$. The mean reduction in growth velocity during treatment with $200 \mu \mathrm{g}$ and $800 \mu \mathrm{g}$ budesonide was $0 \cdot 11$ ( $95 \%$ confidence interval -0.15 to 0.37 ) $\mathrm{mm} /$ week and $0.36(0.13$ to 0.59$) \mathrm{mm} /$ week respectively. During treatment with $400 \mu \mathrm{g}$ budesonide at the end of the trial a reduction of $0 \cdot 17(-0 \cdot 10$ to $0 \cdot 45) \mathrm{mm} /$ week was found.

Mean pulmonary function at hospital and at home and use of $\beta_{2}$ agonists in 14 children with mild asthma during treatment with placebo and budesonide

\begin{tabular}{lcccc}
\hline & $\begin{array}{c}\text { Forced } \\
\text { expiratory } \\
\text { volume in } \\
\text { Period }\end{array}$ & $\begin{array}{c}\text { Peak expiratory } \\
\text { flow }(\mathrm{l} / \mathrm{min})\end{array}$ & $\begin{array}{c}\text { Use of } \beta_{2} \\
\text { stimulants } \\
\text { (puffs/day) }\end{array}$ \\
\hline Placebo 1 & 1.99 & 281 & 287 & 0.8 \\
Budesonide $200 \mu \mathrm{g} /$ day & 1.96 & 288 & 292 & 0.8 \\
Placebo 2 & 1.99 & 295 & 297 & 0.6 \\
Budesonide $800 \mu \mathrm{g} /$ day & 1.99 & 298 & 302 & 0.8 \\
Budesonide $400 \mu \mathrm{g} /$ day & 2.00 & 301 & 304 & 0.7 \\
\hline
\end{tabular}

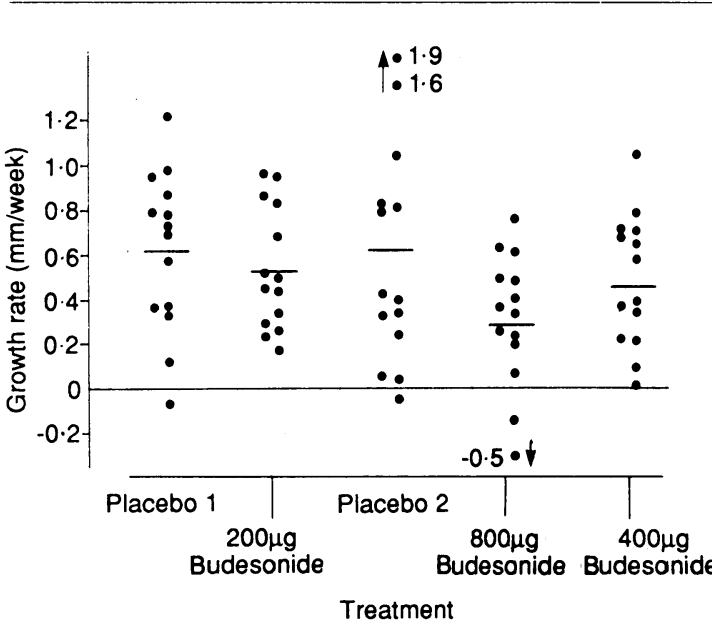

Lower leg growth velocities in 14 children during placebo periods, double blind treatment with $200 \mu \mathrm{g}$ and $800 \mu \mathrm{g}$ budesonide, and open treatment with $400 \mu \mathrm{g}$ budesonide per day

Two children presented with non-febrile earache of two days' duration during the $200 \mu \mathrm{g}$ and $800 \mu \mathrm{g}$ budesonide periods. A mild common cold was observed in three children during run in, in two during treatment with $200 \mu \mathrm{g}$ budesonide, and in one during treatment with $400 \mu \mathrm{g}$ budesonide. No side effects ascribable to budesonide were recorded.

\section{Discussion}

Despite an extensive literature on the topic of growth in children with asthma uncertainty still exists about the severity and frequency of growth impairment that may be attributable to the disease or its treatment. Genetic, hormonal, nutritional, psychological, and socioeconomic factors, age of onset and severity of the disease, hypoxaemia, pulmonary infections, and variations in the therapeutic regimen have all been suggested as influencing growth in asthmatic children. ${ }^{14} 30-34$ So many variables make evaluation of growth data in asthmatic children a formidable task and preclude a meaningful assessment of the relation between one single factor and linear growth in conventional growth studies. In the present short term study we tried to keep all factors that might influence growth 
at a constant level. Only the treatment varied from one period to another. Under these conditions it was found that the mean growth velocity was constant and reproducible during placebo periods; therefore the reduction in growth velocity during budesonide treatment must have been caused by the inhaled drug. The suppressive effect of $800 \mu \mathrm{g}$ budesonide was, however, found to be less pronounced than the suppression caused by taking $2.5 \mathrm{mg}$ prednisolone a day (mean growth velocity $=0.04 \mathrm{~mm} /$ week). ${ }^{24}$

It must be remembered that the $400 \mu \mathrm{g}$ budesonide period was not blind. This period was added to the study at a time when the children had been visiting the clinic twice weekly for a period of about 10 weeks and some of them may have been less motivated than earlier in the study. We do not know if or how this may have influenced the results from that period.

There are no randomised, controlled data elucidating the relation of a short term growth suppressive effect of inhaled glucocorticosteroids and long term growth. It is difficult to extrapolate changes in short term growth velocity in the lower leg to long term growth in stature because of an inherent variability of growth in the lower leg, which may proceed in series of lulls and spurts. ${ }^{2135}$ Furthermore, age is an important factor to consider when evaluating growth during long term treatment, because some findings indicate that children in their teens may be less sensitive to the growth suppressive effect of glucocorticosteroids than children of the ages that we investigated. ${ }^{36}$ As well, it should also be emphasised that our study group consisted of children with mild asthma because we wanted to minimise any possible influence on growth due to poor control of asthma. These children would not normally be treated with high doses of inhaled glucocorticosteroids. In clinical practice high doses are restricted to children with severe asthma, a condition that in itself may retard growth. ${ }^{31}{ }^{34}$ Perhaps the growth suppressive effect of inhaled glucocorticosteroids in these children may be counterbalanced to some extent by the beneficial anti-inflammatory effect of the drug? This needs further study. Considering these questions, however, we think that our data indicate that in clinical practice it is safe to use low doses of inhaled budesonide in schoolchildren with mild and moderate asthma; high dose treatment should be reserved for children with severe asthma.

The results of this study indicate that knemometry is a powerful tool for monitoring the systemic effect of inhaled glucocorticosteroids in children. The method may provide a unique possibility of defining safe doses, dosage regimens, and methods of administration.

This study was supported by grants from the Danish Medical Research Council (12.9009 and 12-9284).

1 Goldstein DE, Koenig P. Effect of inhaled beclomethasone dipropionate on hypothalamic-pituitary-adrenal axis function in children with asthma. Pediatrics 1983;72:60-4.

2 Williams H, Read GF, Verrier-Jones ER, Hughes IA. Effect of inhaled Williams H, Read GF, Verrier-Jones ER, Hughes IA. Effect of inhaled
beclomethasone dipropionate on saliva cortisol concentrations. Arch Dis beclomethasone dipropic $1984 ; 59: 553-6$.

3 Wyatt R, Waschek J, Weinberger M, Sherman B. Effects of inhaled beclomethasone dipropionate and alternate-day prednisone on pituitaryadrenal function in chingren with chronic asthma. $N$ Engl F Med 1978;299:
1387-91.

4 Vaz R, Senior B, Morris M, Binkiewitz A. Adrenal effects of beclomethasone inhalation therapy in asthmatic children. $f$ Pediatr 1982;100:660-2.

5 Law CM, Marchant JL, Honour JW, Preece MA, Warner JO. Nocturnal adrenal suppression in asthmatic children taking inhaled beclomethasone dipropionate. Lancet 1986;: $942-4$.

6 Pedersen S, Fuglsang G. Urine cortisol excretion in children treated with high doses of inhaled corticosteroids: a comparison of budesonide and beclo-
methasone. Eur Respir f 1988;1:433-5.

7 Pedersen S. Safety of inhaled glucocorticosteroids. In: Hargreave FE, et al, eds. Glucocorticoids and mechanisms of asthma. Amsterdam: Excerpta Medica, 1989:40-51.

8 Godfrey S, Koenig P. Treatment of childhood asthma for 13 months and longer with beclomethasone dipropionate aerosol. Arch Dis Child 1974;49: $591-6$.

9 Francis RS. Long-term beclomethasone dipropionate aerosol therapy in juvenile asthma. Thorax 1976;31:309-14

10 Kerrebijn KF. Beclomethasone dipropionate in long-term treatment of asthma in children. $\mathcal{F}$ Pediatr 1976;89:821-6.

11 Godfrey S, Balfour-Lynn L, Tooley M. A three- to five-year follow-up of the use of the acrosol steroid, beclomethasone dipropionate, in childhood asthma. F Allergy Clin Immunol 1978;62:335-9.

12 Graff-Lonnevig V, Kraepelien S. Long term treatment with beclomethasone dipropionate aerosol in asthmatic children, with special reference to growth. Allergy 1979;34:57-61.

13 Bahn GL, Gwynn CM, Smith JM. Growth and adrenal function of children on prolonged beclomethasone dipropionate treatment. Lancet 1980;i:76-7.

14 Balfour-Lynn L. Growth and childhood asthma. Arch Dis Child 1986;61 1049-55.

15 Schueller CF. Budesonide: a twelve month tolerance study in children. Eurf Respir Dis 1986;69(suppl 146):A152.

16 Nassif E, Weinberger M, Sherman B, Brown K. Extrapulmonary effects of maintenance corticosteroid therapy with alternate-day prednisone and inhaled beclomethasone in children with chronic asthma. $\mathcal{F}$ Allergy $\mathrm{Cl}$ Immunol 1987;80:518-29.

17 Ribeiro LB. A 12 month tolerance study with budesonide in asthmatic children. In: Godfrey S, ed. Glucocorticoids in childhood asthma. Amsterdam Excerpta Medica, 1987:95-108

18 Littlewood JM, Johnson AW, Edwards PA, Littlewood AE. Growth retardation in asthmatic children treated with inhaled beclomethasone diproprionate. Lancet 1988;i:115-6.

19 Stead RJ, Cooke NJ. Adverse effects of inhaled corticosteroids. $B M \mathcal{F}$ 1989;298:403-4

20 Valk IM, Langhout Chabloz AME, Smals AGH, Kloppenborg PWC, Cassorla FG, Schutte EAST. Accurate measurements of the lower leg length and the ulnar length and its application in short term growth measurement. Growt 1983;47:53-66.

21 Hermanussen M, Geiger-Benoit K, Burmeister J, Sippell WG. Knemometry in childhood: accuracy and standardization of a new technique of lower leg length measurement. Ann Hum Biol 1988;15:1-16.

22 Wales JKH, Milner RDG. Knemometry in assessment of linear growth Arch Dis Child 1987;62:166-71.

23 Hughes I. Steroids and growth. BMF 1987;295:683-4.

23 Hughes I. Steroids and growth. BMF 1987;295:683-4.
24 Wolthers OD, Pedersen S. Short term linear growth in asthmatic children

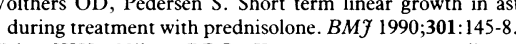

25 Wales JKH, Milner RDG. Knemometry as a predictor of response to ales JKH, Milner RDG. Knemometry as a predictor of response
somatrem in Turner's syndrome. Acta Paediatr Scand 1987;337(suppl): 37-9.

26 Wit JM, Van Karlsbeek EJ, Van Wijk-Hoek JM, Leppink GJ. Assessment of the usefulness of weekly knemometric measurements in growth studies. Acta Paediatr Scand 1987;76:974-80.

27 Feinstein AR. Clinical biostatistics. St Louis: Mosby, 1977:320-34

28 Hills M, Armitage P. The two-period cross-over clinical trial. Brf Clin Pharmacol 1977;8:7-20.

29 Hollander M, Wolfe DA. Nonparametric statistical methods. New York: Wiley, 1973:147-50.

30 Murray AB, Fraser B, Hardwick DF, Pirie G. Chronic asthma and growth failure in children. Lancet 1976;ii: 197-8.

31 Hauspie R, Susanne C, Alexander F. Maturitional delay and temporal growth retardation in asthmatic boys. $\mathcal{F}$ Allergy Clin Immunol 1977;59:200-6.

32 Friedman M, Strang LB. The effect of corticosteroid and ACTH therapy on growth and on the hypothalamic pituitary adrenal axis of children. on growth and on the hypothalamic
Scand I Resp Dis 1969;suppl 68:58-69.

33 Snyder RD, Collipp PJ, Greene JS. Growth and ultimate height of children with asthma. Clin Pediat 1967;6:389-92.

34 Falliers CJ, Szentivanyi J, McBride M, Bukantz SC. Growth rate of children with intractable asthma. $\mathcal{F}$ Allergy 1961;32:420-34.
int

35 Hermanussen M, Geiger-Benoit K, Burmeister J, Sippell WG. Periodical changes of short term growth velocity ("mini growth spurts") in human growth. Ann Hum Biol 1988; 15: 103-9.

36 Kerrebijn KF, De Kroon JPM. Effect on height of corticosteroid therapy in asthmatic children. Arch Dis Child 1968;43:556-61.

(Accepted 24 May 1991)

\section{ONE HUNDRED YEARS AGO}

Shortly before his death the late Mr. Maybrick made what was practically a will, in which he directed that his widow should have the interest derived from a policy of life insurance which he had effected. After the conviction of Mrs. Maybrick, her solicitor brought an action against the insurance company to recover the amount of this policy. This was resisted by the company on the ground that, as she had murdered her husband, Mrs. Maybrick had forfeited all claim to the money. The case was tried this week before two judges, and the contention of the company was upheld. The action, though not in

her name, was unquestionably for her benefit, and whether she knew of the existence of the policy or not, it seems to be obvious that she could not be allowed to benefit by her husband's murder. Whilst we think the company did only their duty in resisting the claim, we hope they will see their way to carry out the ultimate intentions of Mr Maybrick, for he directed that the money should be invested in the names of his brothers as trustees for his children, his widow, meanwhile, during her life, receiving the interest.

(British Medical fournal 1891;ii:197) 